\title{
Sexual violence against children and youth: Exploring the role of congregations in addressing the protection of young girls on the Cape Flats
}

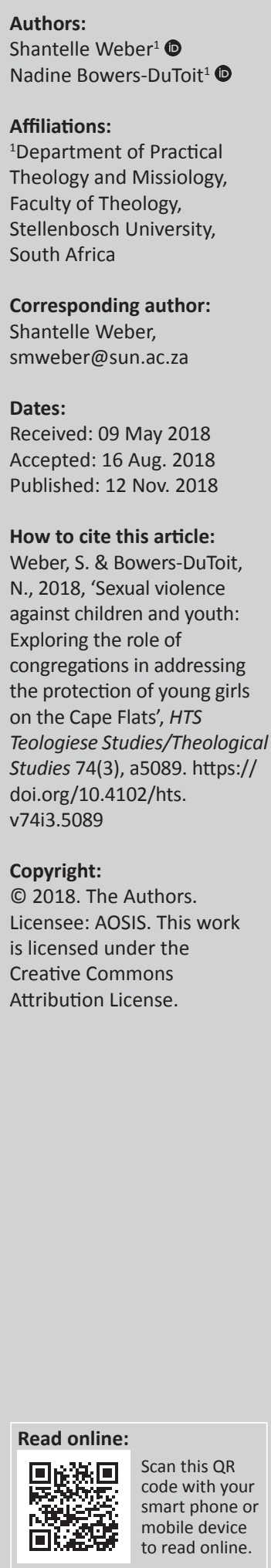

The Children's Institute, a research arm of the University of Cape Town, reports that 18.5 million children live in South Africa. The institute's vision is for 'A society in which children are valued, nurtured and protected; their rights are realised; and where they are able to participate, develop and reach their full potential'. A quick scan of South African newspaper headlines, however, reflects numerous accounts of the abduction, rape and murder of young girls on the Cape Flats in Cape Town, South Africa, during 2016-2017. This seems to confirm the statistic that one in three children is a victim of sexual violence and physical abuse before the age of 18. Sadly, many of these instances are alleged to have been linked to a family member or close family friend. Some have even been linked to Christian church contexts. This article explores this unacceptable rise in violence against these young girls and from this vantage point continues to more specifically reflect on the role congregations can play in such instances. The article argues that such abuse takes place within an ecosystem of violence and then considers how the trauma of such an experience has affected the faith formation of these young girls. The article, furthermore, highlights the recent publication entitled 'Children, Church and the Law', which calls for the establishment of church policy on the protection of children in our local congregations and communities as one preventative and educative tool in addressing this issue.

\section{Introduction}

South Africa is an endemically violent society, and shocking statistics by researchers from the University of Cape Town (Etheridge 2017) reveal that one in every three young South Africans has experienced some form of sexual violence in their lives. What is more shocking is the fact that by November 2017, 66 child and youth murders were recorded in the Western Cape in one year, with most of these related to abuse and neglect (Matthews \& Martin 2017; Mngadi 2017). Many of these murders took place in an area called the Cape Flats in the Western Cape (places such as Mitchells Plain, Lavender Hill, Khayalitsha and Elsiesriver).

Christian organisations like Hope House Counselling noted that trauma and violence were an all too common occurrence in the country, yet victims of abuse have up to a 6-month delay in attaining child abuse intervention in the province (Mngadi 2017). Moreover, the rates of sexual abuse of children and youths have been declared so dire that a commission of inquiry was appointed to investigate the prevalence of such forms of violence. Sociological researchers focussed on children and youth have appealed for 'all professionals who are meant to protect children' to accept responsibility and work together to implement protection strategies (Matthews \& Martin 2017). The challenge to society as a whole - and therefore also civil society role players such as the local congregation - should be to create an enabling environment in which children are nurtured and cared for in safe and secure homes, and where communities are fostered that 'promote children's well-being across all dimensions' (The Star 2017).

This article has, to a large extent, been motivated by our 'situatedness' in the Western Cape Province of South Africa as well as our respective fields of specialisation in youth work, theology and development. The names and faces of three recent cases of abused and murdered young girls, Rene Roman (13), Sasha Leigh Arends (11) and Sinoxolo Mafevuka (19), are mere reflections of the overwhelming number of young girls being abused in this context. Such images and news reports haunt us as mothers who live and worship in these community contexts. Our fields have led us towards an understanding of the complexity of the issue of violence against female children and youth in places such as the Cape Flats, and therefore, we express the need 
in this article to explore this topic from an intra- and interdisciplinary perspective. As a result, the article covers a wide range of intersecting perspectives on the topic. It begins with a discussion of what is termed an 'ecosystem of violence' and the notion of continuous trauma within an area such as the Cape Flats. This is followed by a discussion of local congregational ${ }^{1}$ response to trauma and sexual abuse and an exploration as to how young people's faith formation is affected by such abuse. The articleends with recommendations as to how these local congregations can better respond in addressing the protection of female children and youth in areas such as the Cape Flats. The intention has not been to focus specifically on the lives of the three girls mentioned above but to reflect on these as reason for academic investigation into communities where the reasons for such levels of violence are not necessarily explored. There are varying scholarly understandings of children and youth. This article conceptualises children and youth according to the National Youth Act of 1996, which defines youth in South Africa as persons in the age group of 14 to 35 years, with early youth being 14 to 24 years old and later youth or early adulthood being 25 to 34 years old (National Youth Policy 2009). Emphasis is placed on early youth.

\section{The prevalence of sexual violence against young girls in South Africa}

According to the 2016 annual report of the Children's Institute (2016:3), one in three children or youths is a victim of sexual violence and physical abuse before the age of 18 . The most common forms of violence are physical and sexual abuse, which takes place either in homes or in the broader community (Matthews \& Benvenuti 2014:27). Le Roux (2012:51) agrees that '... South African children between the ages of 12 and 17 years old are more likely to be raped' than any other age. According to Matthews and Benvenuti (2014):

Social acceptance or tolerance of various forms of violence (such as intimate partner violence and corporal punishment) is a major factor in the continued perpetuation of violence. These social norms are carried forward from one generation to the next as men are viewed to have authority over women and children in the family and the community. The patriarchal (male-centred) South African society legitimises violence against women and children as a means of maintaining men in a position of power and control. In addition, widespread violence in communities desensitises children and normalises the use of violence. (p. 29)

This article has specific relevance to young girls. Gender dynamics also play a role, and statistics indicate that in the past year, most of the violence has been against girl children. Mathews and Benvenuti (2014:33) note, for example, that 'gender hierarchy combined with the powerlessness of children fuel the high levels of violence against children'. Gender hierarchies raise not only the issue of power but also

1.The term 'congregation' has been chosen to refer to Christian contexts in which local ministry takes place. The term 'faith communities' is too broad a term to refer to when discussing a complex issue such as childhood violence. the manner in which systems (whether ecclesial or community wide) reinforce destructive patterns of power and ultimately abuse. Palm (2018) argues that:

[c] hildren are often presented as being at the bottom of a hierarchy of human importance, where a father historically held the power of life and death over 'his' household as God's representative. In this authoritarian system, men wield power over women, adults over children ... (nl)

A study conducted in 2016 by the Children's Institute and other members of the Safety and Violence Initiative (SaVI) at UCT revealed that emotional, physical and sexual abuse suffered by women as children was found to be a key determinant of whether they later became victims of violence.

A Child Abuse Tracking (CAT) study revealed that if physical abuse is not taken seriously, because of factors such as lack of therapeutic services, poor record-keeping which prohibits evidence-based planning, poor case management and lack of co-ordination between professionals, increased trauma and continued abuse are the outcomes (Children's Institute Annual Report 2016:14-15). In South Africa, the Sexual Offences and Related Matters Amendment Act 5 of 2015 allows 12- to 16-year-old children the right to have consensual sexual intercourse without it being charged as a crime (Greathead 2016:48). This law also allows a 2-year age gap as legally possible before it being considered as a crime. This creates challenges to the growing reports of date rape among youth in this country. This same act states that if an adult (18 and up) has sexual intercourse with a 12- to 16-year-old child (even with consent), it is a crime (Greathead 2016:49). Convicted offenders' names are then placed on a sexual offenders register and they are prohibited from future work with children and youth. The above-mentioned act considers incest, sexual exploitation of children, sexual grooming of children, exposing children to pornography and using these for pornography, flashing and causing children to witness sexual offenses and masturbation as a crime (Greathead 2016:49-50). Many of these offences form part of the too often reported crimes mentioned in our South African newspapers. Many parents (and even church leaders) do not realise that what young girls are exposed to through daily media may be impacting their faith formation in life-changing ways. This lack of awareness of what sexual abuse entails has been part of the reason as to why many adults in congregations have not felt comfortable educating their children concerning the dangers of such violence. It is sad to note that these congregational contexts have been spaces in which these offenses have taken place.

\section{The Cape Flats: An ecosystem of violence}

\section{Towards a definition of an ecosystem of violence}

In the 2014 UNICEF South Africa Child Gauge report (Matthews et al. 2014), violence against children is defined in several ways, with the World Health Organization's (WHO) definition being presented in this report as the broadest: 
The intentional use of physical force or power, threatened or actual, against a child by an individual or group, that either results in or has a high likelihood of resulting in actual or potential harm to the child's health, survival, development or dignity. (Author's own italics)

In this definition, threatened or actual use of physical force is identified as violence. What is striking with regard to this particular Child Gauge report under discussion is its identification of risk factors as having close ties to socioeconomic disadvantage (Mathews \& Benvenuti 2014:31). Abuse is viewed, therefore, within an ecosystem - which not only includes the perpetrator and victim or survivor but also the various socio-economic and political factors in community and broader society which form a high-risk system which has in the words of the WHO's definition 'a high likelihood of resulting in actual or potential harm to the child's health, survival, development or dignity' (Matthews \& Benvenuti 2014:26).

Societal factors such as education and income, high community level, high crime rates, poor social services and societal level high unemployment rates, high inequality and social exclusion are, therefore, all key in determining the risks of children.

According to the World Bank report, poverty remains racially skewed, and higher risk factors are associated with 'the less educated, the unemployed, female-headed households, large families, and children'. It is also reported that poverty remains concentrated in previously disadvantaged areas (Head 2018). Areas such as the Cape Flats from which the many abused and murdered children mentioned earlier come are some of the poorest areas - a direct result of the systemic violence of the Apartheid state whose legacy remains today. The Cape Flats itself came into existence as the result of the Group Areas Act 1950, which forcibly removed black and coloured people from areas which were then declared 'whites only' and moved to the edges of the cities to what may be termed 'urban ghettos' (Adhikari 2005:3). These areas soon became gang hotspots, with the urban planning (or lack of planning) of social housing and few amenities aggravating the social fabric already frayed by these removals (MacMaster 2007:278).

In 2016, it was reported that a total of 966345 children had received a child support grant within the Western Cape, of which 337168 were between 0 and 5 years old; 364194 between 6 and 11 years old and 264983 between 12 and 17 years old (Hall 2016:114). Other complex factors include educational and even sanitation challenges. Lack of access to adequate water is closely related to poor sanitation and hygiene and may even put girl children at risk of rape. The intersection between lack of amenities and sexual violence is no more striking than in the story of a 19-year-old Khayalitsha girl, Sinoxolo, who was raped and killed while relieving herself in a toilet on the outskirts of her township. The fact that she lived in a shack and had no access to proper sanitation made her extremely vulnerable to sexual predators (Mortlock 2016).
Each of the abused and murdered children and youth such as those mentioned in the introduction have their own stories. At the same time, however, it is important to note that most of these stories have one thing in common - the majority of them come from the impoverished townships of the Cape Flats. We have discussed the intersection of varying complex factors linked to possible causes for violence committed against young girls on the Cape Flats. For children from lowincome communities, which because of the lingering structural inequality of the past receive poor social services, have high crime rates and have parents who are often unemployed or seldom present, the picture is grim. Local congregations within such impoverished communities grapple with these issues on a daily basis. The faith of young girls within such contexts cannot be ignored.

\section{Violence and continuous trauma on the Cape Flats}

Clark, in exploring the causes of youth violence in South Africa, cites Galtung's differentiation between what he termed 'direct violence' and 'structural violence'. While direct violence entails the 'infliction of physical violence ... the general formula for structural violence is inequality, above all in the distribution of power ...' (2012:80). It is the prevalence of structural violence in the form of poverty and inequality, Clark furthermore argues, that 'helps to explain the country's high levels of direct violence'. It is in terms of this explanation that poverty, unemployment and other socio-economic issues could also be considered as forming a 'backdrop' to youth violence ${ }^{2}$ against children and youth (Clark 2012:81).

Many of the gang members on the Cape Flats are recruited from a young age and form part of perpetuating the aforementioned ecosystem of violence. In recent years, scholars have begun to explore the notion of 'continuous trauma'. Although studies have largely been investigated with regard to war and terror contexts, research indicates that contexts where children and youth are exposed to continuous direct violence have been shown to have had farreaching implications for long-term emotional, behavioural and cognitive adjustment beyond post-traumatic stress disorder (PTSD). Continuous trauma has been coupled with developmental conflicts, depression, risk for suicide, and fear and anxiety as well as behavioural and cognitive effects such as violent and aggressive behaviour and delinquent behaviour (Nuttman-Schwartz 2017:30). What is important to note is that individuals who reside in contexts of continuous stress like the young girls referred to in this article can be buffered by their sense of belonging to community institutions - such as schools and congregations (Nuttman-Schwartz 2017:31).

Although we are not arguing that individual perpetrators should be exonerated because of structural factors, we do

Nowhere in South Africa is the term Cape Flats. Economic factors - the effects of the structurat violence of the past - are Cape Flats. Economic factors - the effects of the structural violence of the past - are not only the root causes of gangsterism but also play a role in sustaining gangs so much so that some members of the communities rely on economic support of the gangs to survive (MacMaster 2007:284). 
wish to make the point that 'violence is a socially constructed and a learned behaviour, and cultural and social norms are highly influential in shaping individual behaviour including the use of violence'. The abduction and sexual abuse inflicted upon many girls on the Cape Flats (of which three were cited earlier) are the result of the eco-systems of violence. This is confirmed by a recent Human Sciences Research Council (HSRC) study, which focused on Khayalitsha and found that ' $40 \%$ of primary school learners in Khayelitsha township, in Cape Town, have experienced sexual violence at the hands of other learners or teachers in the past year' (Van Dyk 2018). Furthermore, it is important to note for the purposes of this article that children's decisions to report abuse were also affected by whether they believed it was wrong or not. The research shows $40 \%$ of high school and primary school students who had experienced intimate partner violence did not think it was a violation (Van Dyk 2018).

The majority of victims were girls. This was noted as rooted in the belief that 'violence against women was a normal part of heterosexual relationships' (Van Dyk 2018). This article assumes that congregations ministering in such dire contexts need to carefully consider how this perceived cultural norm impacts the faith formation of these young girls. These congregations may need to review the type of children, youth and family ministries they offer in such contexts.

\section{Youth faith formation, trauma and the church}

This article reflects on the role of churches in the fight against violence affecting female children and youth. With this in mind, research conducted in various African countries found that congregations were not engaging with the issues of sexual violence against children and youth and in some instances actually perpetuated the patriarchal culture that promotes this behaviour (Le Roux 2012:51-55). LeRoux's (2012) research also revealed that survivors of abuse did not feel that the church was a safe space to share about this abuse. This was especially so in contexts where young girls were a marginalised voice of congregational ministry:

SV (sexual violence) is like the proverbial elephant in the room; the church knows what is going on in the community, but pretends and attempts to be unaware of it. (p. 52)

Having shared a brief window into the prevalence of violence and even more specifically sexual violence among young girls in areas such as the Cape Flats, we now shift our attention to how this life-changing traumatic experience impacts the faith formation of these young girls.

Rakoczy (2004:374) posits that '[s]pirituality weaves together a woman's conviction of her dignity as a human person loved by God', and this includes how she views and approaches God. This spiritually exhibits in one's entire being the beliefs, practices and values we hold. Theologian Andrew Schmutzer (2008:785) asserts that ignoring the sexually broken among us is rejecting the ethics of biblical community, a breakdown the abused have already endured.
To act in the area of practical theology is to act in the name of the Church, not just to act on the basis of one's own personal, private authority. (Rossler in Schweitzer \& Van der Ven 1999:33)

This statement is helpful when working in the area of children and youth ministry because this ministry is part of the church and not an exclusive entity. Research focussed on the faith formation of young girls should include the moral and societal challenges these girls face. The daily lived realities of the girls being sexually abused would impact how they experience their faith. Congregations through their children and youth ministry should create spaces in which God is discovered amidst these youth's exploration of self and their identity. The theological nature of this article is grounded in an understanding of children and youth ministry as theologically based in the covenant of God's faithfulness toward young people. This then means that growing of their faith requires that the family functions as the main centre of religious teaching and the congregation as the sphere in which faith formation is motivated and facilitated (Nel 1998:13-25). In essence, the faith of young girls is just as much a priority as that of the adults in their local congregation.

Children and youth faith formation cannot be discussed apart from the societal or cultural contexts in which the youth exist (Weber 2014). This faith formation is understood as the transformative process in which a personal relationship with Jesus Christ and a commitment to the Word of God is prioritised. This is a life-long process because faith formation is impacted by the developmental and contextual issues children and youth face. In this instance the disrupted sexual development of young girls who are sexually abused cannot be ignored when congregations, families and church leaders explore how best to enhance the faith formation of these. Likewise, the abusive contexts into which such children and youth grow up should be considered in how we approach children and youth ministry within ecclesial and community contexts. Many of the instances of sexual abuse in the Western Cape have been reported as incest (i.e. abuse by a family member). This then means that the above-mentioned abusive contexts include the familial contexts as well.

Herman (1992) states that trauma affects one's meaning, trust and hope. Janoff-Bulman (1992) adds that trauma shatters ones fundamental assumptions, including our core notions of religion. This causes a sense of meaningfulness of the world, lack of self-worth, questions about faith and God images being thwarted resulting in a need to earn God's approval. Victims of sexual abuse juggle through feelings of God failing them versus them failing God. In many faith traditions, the perception of God's omnipresence and referral to God as father is challenged. In her study entitled 'The impact of sexual trauma on survivors' theological perception and spiritual formation', Wyckoff (2016) examined the ways in which experiences of sexual abuse interface with survivors' theological perception and faith formation.

Wyckoff (2016:4) argues that most discussions about faith formation fail in considering how images connected to one's 
sexual trauma profoundly shape the ways in which young girls live and grow as spiritual beings. Churches are spaces for and communities of people seeking to grow in their awareness and experience of God, but do not often consider how one living in a sexually abused body may be experiencing the God we preach about. If those who seek to offer spiritual care - pastors, church leaders, spiritual directors and so on - do not fully take into consideration the ways in which sexual trauma interfaces with faith formation, their efforts will be misguided at best and further victimising at worst (Wyckoff 2016:4). Wyckoff's research (2016:8) has revealed that trauma impacts the neurological sequencing of young children's brains, which in practice affects their mental health. This means that besides anger, depression and anxiety being common symptoms of abuse, the abuse itself and its neurological impact often lead to further victimisation. Judith Herman (1992:29) adds that 'because post-traumatic symptoms are so persistent and so wide-ranging, they may be mistaken for enduring characteristics of the victim's personality'. This could result in young girls' sexual trauma being mistaken as misconceived behaviour. Rakoczy (2004:377) argues that this is one of the reasons why women tend to welcome the image of God as healer and friend instead of God as judge. Young girls who are sexually abused not only experience physical, emotional and cognitive trauma but spiritual trauma as well.

Children and youth ministry should focus on faith formation practices that lead to the life-giving nurturing of the soul rather than further victimisation and wounding (Wyckoff 2016:3). Conversely, congregational leaders should also teach these traumatised girls that having faith does not mean that one does not experience trials and suffering in one's life. Parks (2000:24) warns against the assumption that having faith leads to a life without challenges and suffering. Faith can easily be focussed on things other than the triune God, resulting in it being restricted to a suffering-free life. Jesus Christ learned obedience through suffering (Wilhoit 2008:41). Faith becomes realised as truth and trust once tested by suffering and trials, thus learning to see God in increasingly adequate ways. One's understanding of faith therefore cannot be separated from the reality of betrayal, suffering, fear and even amazement. Young girls who have already experienced life within such eco-systems of violence and now dealing with sexual abuse are not exempt from these trials and faith, and we should not communicate the Christian faith to them as a magic wand in which all suffering disappears. This lived and active faith is linked to an awareness of living one's life aligned with a sense of purpose and significance (Parks 2000:26). It involves actively seeking and discovering meaning in the most comprehensive dimensions of one's experience as a human being (Parks 2000:7). The children and youth require consistent mentorship relationships journeying alongside them amidst experiencing life's challenges (Weber 2014). The local congregation can assist families by attaching traumatised girls to a spiritually mature mentor. It can also assist by ensuring that youth leaders are trained and equipped to care for or at least detect instances of sexual abuse in the young girls they minister to. Furthermore, congregations can also assist by offering support to families who have been affected by such traumatic experiences.

Biblical references to children (Pr 17:6, 22:6; Ja 1:27; Ps 127:3 and Lk 9:46-48) include the care and nurture of children's well-being as part of the church's (local congregation) mission. 'Children are essential to the life and ministry of the church (and as such) ... The church needs to be a place where children may dynamically connect with God and engage in meaningful participation' (Greathead 2016:52). Research (Crisp 2007 in Wyckoff 2016:10) has indicated that the impact of sexual abuse as a child affects young women's faith as adults as well:

Survivors often lose their sense of agency through forced victimization and some spend many years working to regain a sense of control and power over their lives. In this light, pursuit of a divine plan can feel less than desirable, if not utterly victimizing. Survivors' perception of God is informed in part by their traumatization. Many survivors both feel ashamed of themselves and believe God is ashamed of them, a dangerous and damaging internalization of their victimization. Many survivors often note difficulty in trusting God. When survivors are abused at the hands of someone they know, they often find it difficult to trust in relationships. This difficulty is increased when the abuser was in a position of authority who neglected his/her role as a caretaker and instead inflicted harm on a child.

One theological teaching (among many) that victims of sexual abuse struggle with along their faith journey has been the omniscience, omnipotence and omnipresence of God. They wrestle with a God who is all present, all knowing and all powerful yet allowed their embodied experiences of abuse and suffering. There are young girls who even grapple with biblical texts such as the rape of Tamar, wondering whether the Bible condones such behaviour. Biblical scholar Claasens (2015) argues that we should assist women who are traumatised through gender-based violence in finding their connection with the traumatic narratives within the text rather than marginalising them further. The encouragement is to explore the Bible with these girls rather than interpret it for them. There are however some who have found solace and restoration in being part of a local congregation that offers holistic support alongside faith formation. For these:

spirituality appeared to act as a source of strength, to aid in the process of meaning-making, and to provide a source of inner strength and belief in self for those women survivors. (Crisp 2009 in Wyckoff 2016:12)

Another contestation has been the teaching about God as father. Victims of incest find this hard to accept when they have lived through sexual abuse committed by their fathers, close uncles and grandfathers. Youth leaders, church leaders and congregations as a whole need to be aware of the implications of such teachings within the context of sexual abuse. Training around how to minister to such young girls need to take these into careful consideration. It must also be cautioned that grappling with one's faith journey is not a simplistic step-by-step process. This is even more complex 
for girls who are grappling with the possible absence of God from their story. According to Rakoczy (2004:383), young girls should be encouraged to discover who they are in Christ and how their trauma can be explored within a greater life narrative written by God for them.

\section{Recommendations with regard to congregational interventions}

Segura-April et al. (2016:29) have confirmed that local congregations do not prioritise their children and youth. Ministerial focus has been on adults who are seen as the church today while the next generation is considered the church of the tomorrow. This article has been premised on the understanding that the congregation and the family of the young girls being discussed here play an integral role in their faith formation. This then requires that the social, cultural and religious worldviews that sustain and underpin a position of vulnerability for children and youth are challenged. Faith communities are accountable to God for creating safe spaces in which young girls who have been abused can be vulnerable in sharing about what is happening to them. Creating such safe spaces requires consistent relationships based on conversation and trust. Unfortunately, considering the trauma faced by abused children and youth, addressing issues of trauma and abuse must become a nonnegotiable component of how churches engage both in faith formation practices and the ways in which they respond to the ecosystem of violence within which abuse takes place.

This article has already made reference to various issues which local congregations should consider when working in contexts of eco-systemic violence which have deteriorated to the extent of young girls being abducted and sexually abused on a regular basis. The following are recommendations we believe could further assist congregations on the Cape Flats more specifically to address the challenges faced by sexually abused and traumatised young girls within this context:

1. Local congregations must recognise the ecosystem of violence: Many local church leaders are aware of the state of their communities but they too have become 'used to' the trauma they experience in these contexts because of the effects of continuous trauma. Structural and direct violence cannot be confronted in isolation. Congregations need to unite with each other in forums such as ministers' fraternals and work together with Non-government Organizations (NGOs) and government to advocate for safer schools, afterschool care and even sanitation issues. In communities, where there are often few formal buildings, congregations often have additional communal space for activities such as afterschool or homework programmes, and in this way, congregations could be havens for children and youth from this ongoing violence and should explore how these can become safe spaces in communities where young girls find love, acceptance and space for play.

2. Local congregations must see it as their calling to care for 'the least of these' as God's mission and advocate for them through reporting known cases, counselling services and working with social welfare. Although these actions appear to be logical steps to be taken in the case of abuse, this is often challenging as parents or close relatives are at times involved in the abuse or are even church members. Church leaders, both clergy and lay leaders, must see their responsibility as to the most vulnerable first.

3. Local congregations should be more 'child centric': A proposal for change will necessitate challenging the social, cultural and religious worldviews that sustain and underpin a position of vulnerability of children and youth: In other words, young girls need a new place in our families, our communities, our schools and our congregations. It is biblically mandated that pastoral leadership and parents train up young children and youth and that we encourage their faith formation within the context of these local communities. Our call throughout this article has been based on a holistic approach to faith formation. Congregational faith formation processes should include Christian education about gender, sexuality and power within the relationships youth find themselves in. The example of how Christ treated children, and more so women, encourages that we are more intentional around the issues that impact their faith formation. If these are considered in how we do ministry, these young girls would flourish!

4. Congregations are sternly encouraged to put systems and policies in place that will ensure the protection of children and youth: These systems should include procedures to follow with regard to all activities including children and youth, for example, Sunday School, babysitting offered by churches, outings and so on. All people working with children and youth should be screened and also sign the congregational child protection policy. Procedures to follow when confronted with instances of violence against young girls should be included here (Greathead 2016:131-132). Although the law now requires this, many churches are still lagging in their formal engagement with the child protection framework.

5. Denominational structures can provide ways to help local congregations put into action the above-mentioned policies by offering workshops and seminars: Pastors can be urged to preach sermons and teach Bible studies in order to help all of the members of the church to transform their thinking about children at risk. Le Roux (2012:53) adds that this training should be included within seminary spaces.

6. Partnership with other NGOs and faith-based organisations (FBOs) that work in this field: Local congregations need to find out what other local churches are doing with girl children and youth at risk. It is important that local congregations make a concerted effort to connect with NGOs and FBOs that are working in their area and find out how they might partner with them. In addition, congregations should connect with local schools, social agencies, clinics and other organisations to find out what they might be able to offer 
and how you might be able to partner in addressing community challenges relating to these vulnerable groups (Greathead 2016:66).

7. Youth and children's ministry leaders, pastors working with young girls and parents of these youth and children should be equipped on how to pastorally care for them. It is our belief that if the church is indeed concerned for its next generation, this concern should include responsible faith formation processes which take the identity and moral formation of these young women seriously (Weber 2014).

8. Congregations should be sensitive with regard to the manner in which biblical texts are expounded on within communities in which abuse is so prevalent: Being intentional about knowing who the children and youth we are ministering to is crucial. As noted above, abused young girls grow up with a sense of continuous trauma which could also be connected to how the Bible and certain doctrines have been taught to them. Palm (2018) encourages congregations to also consider contextual Bible readings in this regard.

\section{Conclusion}

In his book, Spiritual Formation as if the Church Mattered, James Wilhoit (2008:13) expresses concern with the erosion of intentional faith formation in the church. He also expresses concern for the extinction of traditional faith formation practices. Wilhoit advocates for the gospel as part of the very being of each believer and not merely as an entry point to the faith. He argues that it is this very gospel that continually renews our minds and hearts as Christians and also enables a transformed church engaged within vulnerable communities like the ones discussed in this article. Rakoczy (2004:384) reminds us that young 'women find God and themselves in their experiences of embodied life, of loving their bodies through the cycles of their lives'. This article began with reflecting on the trauma experienced by young girls by listing the recent cases of three young women on the Cape Flats who have not only being physically violated but also live within an ecosystem of violence. Their daily life experiences and those of many others cannot ignore the social injustices that pervade their opportunities for a 'better' life. We have also argued in this article that the faith of young women like these questions a God with whom they desire an authentic and present relationship. It is our belief that this is only possible through the life-giving power of the gospel, which is intentionally explained and lived for them through the faith communities within their spheres of influence. We also believe that their families and support systems can be empowered through these faith communities taking seriously their responsibility to act justly and show mercy to the least of these.

\section{Acknowledgements Competing interests}

The authors declare that they have no financial or personal relationship(s) which may have inappropriately influenced them in writing this article.

\section{Authors' contributions}

S.W. and B.D.T. jointly contributed to the conceptualisation, research and write-up of this article.

\section{References}

Adhikari, M., 2005, 'Contending approaches to coloured identity and the history of the coloured people of South Africa,' History Compass 3(2005), 1-16.

Children's Institute, 2016, Children's Institute annual report, Children's Institute, University of Cape Town, Rondebosch, South Africa.

Claassens, L.J., 2015, 'Reading for the dignity of all: Overcoming the troubling legacy of the Old Testament', Stellenbosch Theological Journal 1(2), 155-174. https:// doi.org/10.17570/stj.2015.v1n2.a

Clark, J.N., 2012, 'Youth violence in South Africa: the case for a restorative justice response', Contemporary Justice Review 15(1), 77-95. https://doi.org/10.1080/10 282580.2011.653521

Crisp, B.R., 2007, 'Spirituality and sexual abuse: Issues and dilemmas for survivors,' Theology and Sexuality 13(3), 306. https://doi.org/10.1177/1355835807078263

Crisp, B.R., 2009, 'Beyond Crucifixion: Remaining Christian after sexual abuse,' Theology and Sexuality 15(1), 66. https://doi.org/10.1558/tse.v15i1.65

Etheridge, J., 2017, ' 1 in 3 child abuse stats shocking, frightening - MEC', viewed 03 March 2018, from https://m.news24.com/SouthAfrica/News/1-in-3-child-abusestats-shocking-frightening-mec-20160602

Greathead, E., 2016, Children, Church and the Law: A practical guide for churches on the Children's Act and other laws relating to children, The Warehous, Cape Town.

Hall, 2016, in A. Delany, S. Jehoma \& L. Lake (eds.), South African Child Gauge 2016 Children's Institute, University of Cape Town.

Head, T., 2018, Inequality has increased in South Africa since apartheid - World Bank, viewed 10 August 2018, from https://www.thesouthafrican.com/inequalityincrease-apartheid-south-africa/

Herman, J., 1992, Trauma and recovery: The aftermath of violence: From domestic abuse to political terror, Basic Books, New York.

Janoff-Bulman, R., 1992, Shattered assumptions: Towards a new psychology of trauma, Free Press, New York.

Le Roux, E., 2012, 'Why sexual violence? The social reality of an absent church' in J.H. Hendriks, E. Mouton, L. Hansen \& E. le Roux (eds.), Men in the pulpit, Women in the pew? Addressing gender inequality in Africa, pp. 49-60, Sun Media, Stellenbosch.

Mathews, S., Jamieson, L., Lake, L. \& Smith, C. (eds.), 2014, South African Child Gauge 2014, Children's Institute, University of Cape Town, Cape Town.

Matthews, S. \& Benvenuti, P., 2014, 'Violence against children in South Africa: Developing a prevention agenda', in S. Matthews, L. Jamieson, L. Lake \& C. Smith (eds.), South African Child Guage 2014, pp. 26-34, Children's Institute UCT, Cape Town.

Matthews, S. \& Martin, L., 2017, 'Child murders SA's preventable tragedy', viewed 06 March 2018, from https://www.iol.co.za/capeargus/opinion/child-murders-saspreventable-tragedy-11087932

Macmaster, L., 2007, 'Social and economic emasculation as contributing factors to gangsterism on the Cape Flats,' Scriptura 95(2007), 278-280.

Mngadi, M., 2017, Western Cape 66 child murders this year, viewed 06 March 2018 from https://m.news24.com/SouthAfrica/News/western-cape-66-child-murdersthis-year-20171101

Mortlock, M., 2016, No progress after Khayalitsha girl murdered, dumped in toilet, EWN, viewed 03 March 2018, from http://ewn.co.za/2016/03/09/No-progressafter-Khayelitsha-girl-murdered-dumped-in-toilet

National Youth Policy (2009-2014) Document, March 2009. viewed n.d., from https:// www.gov.za/documents/national-youth-policy-2009-2014

Nel, M., 1998, Youth Ministry: An inclusive congregational approach, RGN, Pretoria.

Nuttman-Schwartz, O., 2017, 'Children and adolescents facing a continuous security threat: Aggressive behaviour and post-traumatic stress symptoms', Child Abuse and Neglect 69(2017), 29-39. https://doi.org/10.1016/j.chiabu.2017.04.008

Palm, S., 2018, Church outrage over spanking ban aids violence against South Africa's children, 'The Conversation', viewed 10 March 2018, from https://theconversation. com/church-outrage-over-spanking-ban-aids-violence-against-south-africaschildren-88098

Parks, S.D., 2000, Big questions, Worthy dreams: Mentoring young adults in their search for meaning, purpose, and faith, Wiley Company, Jossey-Bass.

Rakoczy, S., 2004, In her name: Women doing theology, Cluster Publications, Pietermaritzberg.

Schmutzer, A.J., 2008, 'A theology of sexual abuse: A reflection on creation and devastation,' Journal of the Evangelical Theological Society 51(4), 785.

Schweitzer, F. \& Van der Ven, J.A. (eds.), 1999, Practical theology: International perspectives, Peter Lang Publishers, Frankfurt am Main.

Segura-April, D., Greener, S.H., Scott, D., Panotto, N \& Wong, M., 2016, Lausanne occasional article on mission with children-at-risk: A product of the Lausanne consultation on children-at-risk, Lausanne Movement, Quito, Ecuador, November 17-19, 2014.

The Star, 2017, 'Shocking child murder figures', The Star, viewed 06 March 2018, from https://www.iol.co.za/the-star/shocking-child-murder-figures-in-sa-11468849 
Van Dyk, J., 2018, Almost half of Khayelitsha primary school learners have experienced sexual violence, Bhekisa, viewed 16 August 2018, from https://bhekisisa.org/ have-experienced-sexual-violence

Weber, S.M 2014 'Faith formation of young people in an evangelical context: An empirical and theoretical investigation', PhD Dissertation: University of Stellenbosch.
Wilhoit, J.C., 2008, Spiritual formation as if the Church mattered: Growing in Christ through community, Baker Publishing Group., Grand Rapids, MI

Wyckoff, M., 2016, 'The impact of sexual trauma on survivors' theological perception and spiritual formation', Doctoral dissertation presented as partial fulfilment
of the Doctor of Ministry for the Hazelip School of Theology of Lipscomb University. 